\title{
Impact of initial serum ferritin on early post-HSCT complications: a single-center study
}

\author{
Mostafa Shaheen, ${ }^{1,2}$ Maria O. Ivanova, ${ }^{1}$ Ivan S. Moiseev, ${ }^{1}$ Sergey V. Bondarchuk, ${ }^{3}$ Boris V.Afanasyev ${ }^{1}$ \\ 1. R.M. Gorbacheva Memorial Institute of Children Oncology, Hematology and Transplantation, The First St. Petersburg Pavlov \\ State Medical University, St. Petersburg, Russia \\ 2. Hematology and Bone Marrow Transplantation Department, Tishreen Hospital, Damascus, Syria \\ 3. Department of Hematology, Faculty Therapy, S.M.Kirov Military Medical Academy, St. Petersburg, Russia
}

Dr. Mostafa Shaheen, Lebedeva Str 23, St. Petersburg, Russia
Phone: +7-967-432-87-01

E-mail: mostaheart@yahoo.com

\section{Resume}

\section{Introduction}

Iron overload (IO) is an important issue when treating patients who undergo hematopoietic stem cell transplantation (HCT). Elevated pre-transplant serum ferritin levels have been associated with increased morbidity and mortality after allogeneic HCT.

\section{Patients and Methods}

In the single-center study, we have reviewed medical records of ninety-one consecutive patients (42 males and 49 females), with a median age at HCT of 31.6 years (range, 5 to 60 ), who underwent allo-HCT with unmanipulated grafts between Jan 2013 and Dec 2014.

\section{Results}

The median pre-HCT serum ferritin concentration was 765.35 (range, 12.1-4247) $\mathrm{ng} / \mathrm{mL}$ for the total group. Fifty-three patients (58.24\%) had initial serum ferritin of $>500 \mathrm{ng} / \mathrm{mL}$, and were assigned to the high-ferritin group. Increased pre-transplant ferritin concentrations were significantly associated with toxic or infectious complications of HCT, i.e., number of febrile neutro- penic episodes $(\mathrm{P}=0.005)$, number of bacterial infection episodes $(\mathrm{P}=0.009)$, pneumonias $(\mathrm{P}=0.04)$, and demand for multiple $\mathrm{RBC}$ transfusions $(\mathrm{P}=0.04)$ within 100 days post-HCT. The significant association was found between pre-HCT ferritin concentrations ( $>773 \mathrm{ng} / \mathrm{mL}$ ) and overall survival $(\mathrm{P}=0.04)$, disease-free survival $(\mathrm{P}=0.019)$, and mortality $(\mathrm{P}=0.02)$ among the groups. No significant relationships were observed between the initial ferritin levels and incidence of mucositis, or graftversus-host disease $(\mathrm{P}>0.05)$.

\section{Conclusion}

Measurement of serum ferritin, as a surrogate laboratory marker for IO, is quite practical for many hematological clinics. In the present study it was shown that the baseline increase of serum ferritin contents, is associated with higher risk of febrile episodes, infectious conditions, and slower recovery of myeloid cells, thus being of certain predictive value. Of special interest is an association between the pre-transplant ferritin levels and increasing demand for RBC transfusions after allo-HCT.

\section{Keywords}

hematopoietic stem cell transplantation, allogeneic, iron overload, serum ferritin, complications, early infectious, survival. 


\section{Introduction}

Iron takes part in several metabolic processes, including DNA synthesis, oxygen and electron transport. Most of the iron in human body is distributed within hemoglobin $(65 \%$; $2300 \mathrm{mg}$ ). Ca. $10 \%$ is present in muscles and other tissues, e.g., liver (200 mg), macrophages $(500 \mathrm{mg})$, and bone marrow $(150 \mathrm{mg})$ [23].

Ferritin is the main iron storage molecule. It makes ferrous ions available for critical cellular processes, while protecting lipids, DNA and proteins from potentially toxic effects of free iron. Increased iron load may, however, saturate the available transferring pool and lead to excessive levels of non-transferrin-bound iron which may be subsequently captured and stored either within ferritin, or hemosiderin molecules [14].

Therefore, serum ferritin is considered a simple and widely used surrogate marker for IO. However, many confounding factors, particularly in HCT recipients, may result in potential IO overestimation. E.g., inflammation, infections, liver damage and GvHD may also lead to elevated serum ferritin levels [21]. Repeated serum ferritin measurements can reveal potential causes and help to establish a general pattern of the iron overload over time.

On the basis of serum ferritin levels, the diagnosis of iron overload has been reported in up to $88 \%$ of long term HSCT survivors. When liver iron content is assessed by MRI technique, the prevalence of iron excess is reported to be $32 \%$ in allo-HCT recipients who survived 1 year or more following HCT [19].

The adverse impact of IO on the HSCT outcome was first demonstrated in thalassemia patients [10]. In MDS patients, a transfusion dependency was considered a prognostic factor in WHO classification-based Prognostic Scoring System (WPSS) and independently associated with reduced OS and increased NRM [1].

Different workers have presumed an iron overload to be a risk factor for clinical complications in HCT recipients, including higher occurrence of mucositis [3], increased infection rates $[2,7,12,15,25]$, liver functions abnormality [9], GvHD severity $[18,6]$, and non-relapse mortality [4].
Hence, the aim of our single-center study was to confirm previous reports and assess a predictive value of the baseline ferritin levels for different early complications of HSCT procedure.

\section{Patients and methods}

We have retrospectively evaluated a group of ninety-one consecutive patients undergoing unmanipulated allo-HCT in R.M. Gorbacheva Memorial Institute of Children Oncology, Hematology and Transplantation at the St. Petersburg Pavlov State Medical University, St. Petersburg, between $01 / 01 / 2013$ and 03/09/2014. The inclusion criteria were as follows: (1) First allo-HCT from HLA-compatible related, unrelated or haplo-identical donors; (2) Primary malignant, or non-malignant disease; (3) Age: 5 to 60 years; (4) Karnofsky performance status $\geq 70 \%$.

The cohort included 42 men and 49 women with a median age at transplantation of 31.6 (range, 5 to 60 ) years. Underlying diseases were acute myeloid leukemia $(n=68)$, myelodysplastic syndrome $(\mathrm{n}=10)$, myeloproliferative neoplasms $(\mathrm{n}=4$; Primary myelofibrosis $=3$, Chronic myelomonocytic leukemia $=1)$, bone marrow failure $(n=7$; Aplastic anemia $=6$, Fanconi anemia=1) and B-thalassemia major $(n=2)$. Stem cell transplants were from (HLA)-identical siblings $(n=16)$, haplo-identical $(n=6)$, or unrelated volunteer donors; $(n=69)$.

The conditioning regimens were myeloablative (MAC) in 26 patients, or reduced-intensity (RIC) in the rest of this group.

The follow-up period was 100 days after allo-HCT. Baseline characteristics of the patients are given in Table 1. We evaluated the effects of high pre-allo-HCT serum ferritin on early toxic, infectious and other complications, as well as early transplant outcomes.

The study was approved by the Institutional Review Board at the First St.Petersburg State Pavlov Medical University. Each patient has given an informed consent for the use of personal data.

\section{Table 1. Patients baseline characteristics}

\begin{tabular}{|l|l|l|l|}
\hline Total number of patients & 91 & $\%$ & Range \\
\hline Male & $42(46 \%)$ & & \\
\hline Female & $49(54 \%)$ & 54 & \\
\hline median age & 31.6 & & (5-60) ys \\
\hline Diagnosis & & & \\
\hline AML & $68(75 \%)$ & 74.70 & \\
\hline MDS & $10(11 \%)$ & 10.90 & \\
\hline
\end{tabular}




\begin{tabular}{|c|c|c|c|}
\hline PMF & $3(3 \%)$ & 3.20 & \\
\hline $\mathrm{AA}$ & $6(6.5 \%)$ & 6.50 & \\
\hline B-Thalassemia major & $2(2 \%)$ & 2.10 & \\
\hline Fanconi anemia' & $1(1 \%)$ & 1.10 & \\
\hline Chronic myelomonocytic leukemia & $1(1 \%)$ & 1.10 & \\
\hline $\begin{array}{l}\text { Status of malignant disease }(\mathrm{n}=82) \\
\text { Complete remission (CR) }\end{array}$ & 53 & 64.60 & \\
\hline non-CR & 29 & 33.40 & \\
\hline Type of allo-HCT MRD & 16 & 17.50 & \\
\hline$M^{\prime} D^{2}$ & 58 & 63.70 & \\
\hline haplo & 6 & 6.60 & \\
\hline MMUD³ 8-9/10 & 11 & 12 & \\
\hline Conditioning regimen $\mathrm{MAC}^{4}$ & 26 & 28.60 & \\
\hline $\mathrm{RIC}^{5}$ & 65 & 71.40 & \\
\hline Source of stem cells BM & 37 & 40.60 & \\
\hline PBSC & 52 & 57.10 & \\
\hline $\mathrm{PBSC}+\mathrm{BM}$ & 2 & 2.20 & \\
\hline median $\mathrm{CD} 34+/ \times 10^{6}$ & 5.07 & & $(1.3-14.1)$ \\
\hline median $\mathrm{CD} 3+/ \times 10^{7}$ & 13 & & $(1.2-39.5)$ \\
\hline Donor M / F & $59 / 311 / ?$ & $64.8 / 31.2$ & \\
\hline median donor age & 32.3 & & (3.9-56) \\
\hline $\mathrm{RBC}$ counts pre-transplant, $\mathrm{M} \pm \mathrm{m}$ & $3.3 \pm 0.07(0.7)$ & & $(1.6-5.0)$ \\
\hline Median Hb concentration g/l & $106.3+2.5(23.6)$ & & $(50-155)$ \\
\hline Mean RBC volume, $\mathrm{f} / \mathrm{L}$ & $97.7+0.8(7.3)$ & & (79.7-117.4) \\
\hline Mean ferritin level pre-allo HSCT ng/ml. normal (11-307) & $765.35+70.9(676.3)$ & & $(12.1-4247)$ \\
\hline $\begin{array}{l}\text { Patient erythrocyte antigens: } \\
\text { A } \\
\text { B }\end{array}$ & $\begin{array}{l}42,9 \%(39 / 91) \\
28,6(26 / 91)\end{array}$ & & \\
\hline $\begin{array}{l}\text { Donor erythrocyte antigens } \\
\text { A } \\
\text { B }\end{array}$ & $\begin{array}{l}42.9(39 / 91) \\
16.5(15 / 91)\end{array}$ & & \\
\hline Major RBC mismatch & $14.3(13 / 91)$ & & \\
\hline Minor RBC mismatch & 23.1 (21/91) & & \\
\hline
\end{tabular}

${ }^{1}$ Matched related donor, ${ }^{2}$ Matched unrelated donor, ${ }^{3}$ Mismatched unrelated donor, ${ }^{4}$ Myeloablative conditioning regimen, ${ }^{5}$ Reduced intensity conditioning regimen, 
The study cohort was divided into 2 groups, those with high versus low ferritin concentration (resp. HF and LF groups), on the basis of a $500-\mathrm{ng} / \mathrm{mL}$ threshold for increased ferritin concentration. Mucositis was graded on a scale of 0 to 4 , according to Common Toxicity Criteria, version 4, from the National Cancer Institute. The International EORTC/MSG Consensus on opportunistic fungal infections (FI) was used for diagnosis of FI [5]

Bacterial infection was defined as recovery of a recognized pathogen from, at least, 2 different sites for 100 Days postHCT (Data Form 2100). Recovery of neutrophils was blood or urine cultures yielding the same organism. For each patient, the numbers of bacterial, viral and fungal infections were calculated, according to CIBMTR registered when reaching the ANC numbers of $>500 / \mu \mathrm{L}$ for the first 3 consecutive days. Acute graft-versus-host disease (aGvHD) was graded according to Gratwohl criteria [11]. A diagnosis of sinusoidal obstruction syndrome (hepatic veno-occlusive disease) was made on the basis of Seattle criteria, as described by McDonald et al [17].

Continuous variables in the 2 groups were compared by means of the Mann-Whitney test. Categorical variables were compared using the Chi-square test. Overall survival and transplant-related mortality were calculated, using the Kaplan-Meier method. Possible risk factors were tested using the log-rank test. Cutoff levels of ferritin amounts were determined using ROC- analysis. The calculations were made with SPSS.19.

\section{Results}

Fifty-three (58\%) patients with increased serum ferritin concentrations ( $\geq 500 \mathrm{ng} / \mathrm{mL}$ ) were classified as the high-ferritin group (HF), with a median of $1148 \mathrm{ng} / \mathrm{mL}$ (range, $650-4247)$. The rest of patients $(n=38,41.76 \%)$ were classified as LF group, and had serum ferritin concentrations $(<500 \mathrm{ng} / \mathrm{mL})$ with a median ferritin level of 232 (range, $12.1-466.3 \mathrm{ng} / \mathrm{mL})$.

Active infections within last month prior to HCT were observed only in HF group, including 8 patients with probable invasive pulmonary aspergillosis; 2 cases of soft tissue infection; purulent sinusitis in 2 patients and fever of unknown origin in 2 cases, with a median ferritin level of $1057 \mathrm{ng} / \mathrm{mL}$ (606-1875). Hence, fungal infections prevailed among total infections by the date of allo-HCT, and $26.14 \%$ of patients in HF group with increased ferritin levels $(\mathrm{P}=0.001$; [OR], 0.73; $95 \%$ confidence interval [CI], 0.62-0.86).

\section{Early complications of allogeneic-HCT}

\section{Mucositis}

Post-transplant mucositis was observed in seventy patients: $28(52 \%)$ in $\mathrm{HF}$ and $19(50 \%)$ in LF group had mucositis grade I-II ( $\mathrm{P}>0.05) .11(21 \%)$ in $\mathrm{HF}$ group versus 12 (32\%) among LF patients had mucositis grade III-IV. No statistical differences were observed between the two groups $(\mathrm{P}>0.05)$.

\section{Febrile neutropenia}

Febrile neutropenia was observed in sixty-seven cases: 42 (79\%) in HF vs $23(60 \%)$ in LF group (P > 0.05). Despite the lack of a significant difference between the groups, we revealed a near-linear correlation between the numbers of febrile neutropenia episodes and increase in the mean ferritin levels (Fig. 1). The median for HF group was 1.5 febrile episodes/patient ( 0 to 6 ) vs 0.84 ( 0 to 3 ) in LF patients [ $\mathrm{P}=$ 0.005; OR, 4.08; 95\% (CI), 1.46-11.42] (Fig.2). Accordingly, the number of patients who required granulocyte colony-stimulating factor (G-CSF) injections in order to boost hematopoiesis and to shorten neutropenic period was: $25(47 \%)$ vs $7(18 \%)$ in the HF and LF groups, respectively [P =0.005; (OR), 0.25 ; 95\%(CI), (0.09-0.67)] .

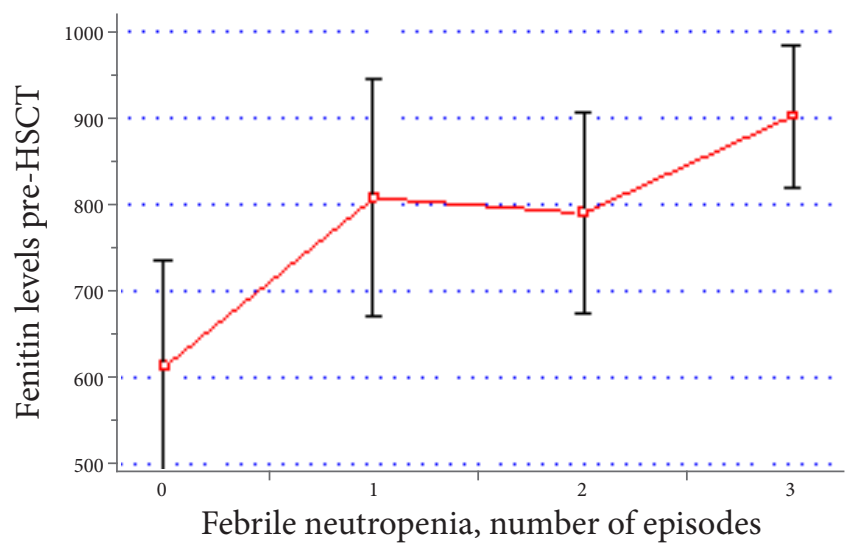

Figure 1. Pre-transplant serum ferritin levels before HSCT in the patients with different numbers of febrile neutropenia episodes posttransplant. Ordinate, mean ferritin levels $(\mathrm{ng} / \mathrm{mL}, \mathrm{M}+\mathrm{m})$. The trend is significant by $\mathrm{P}=0.005$.

\section{Bacterial infections}

Although the percentage of patients with developing bacterial infections was similar in both $\mathrm{H} \mathrm{F}$ and LF groups (resp., 88.64\%, $84.2 \%$ ), there was a distinct correlation between the increased pre-HCT ferritin and median number of infectious episodes/ patient, i.e., 2.7 ( 0 to 7 ) in HF group, and 2.0 (0 to 6) in LF sample $[\mathrm{P}=0.009 ;(\mathrm{OR}), 3.2 ; 95 \%(\mathrm{CI}),(1.31-7.77)]$. Incidence of febrile neutropenia and septicemia post-transplant was more frequent in the HF group $(n=20 ; 30 \%)$ vs LF patients $(\mathrm{n}=8 ; 13 \%)$, at a marginal statistical difference $(\mathrm{P}>0.05)$, as shown in Fig. 1.

Febrile neutropenia and infection

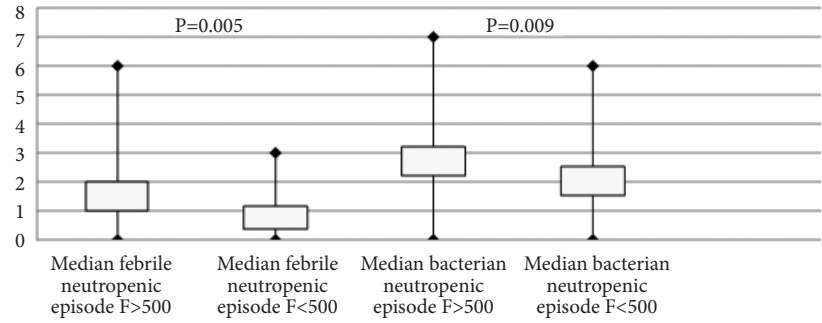

Figure 2 Association between pre allo-HCT serum ferritin and febrile neutropenic and infectious complications after allo-HCT Abscisse, groups with different post-HCT compliations; Ordinate, number of febrile neutropenic episodes (median + range). 
Mixed infections as causes of pneumonia were observed in a large proportion of patients (bacterial, fungal, and viral pathogens): $58.8 \%$ and $60 \%$ in HF and LF groups, respectively.

\section{Fungal infections}

In our cohort study, probable or proven fungal infections were observed in 9 patients (17\%) from HF group (one patient had two episodes) and 3 patients (7.9\%) in LF group, with no statistically significant difference $(\mathrm{P}>0.05)$.

\section{CMV infection}

During the early period after allo-HCT, CMV reactivation was observed in 38 patients ( $42 \%$ of total), including $23(43 \%)$ in HF group, and $15(39 \%)$ in LF patients, without statistically significant difference $(P>0.05)$. Likewise, no differences were found for incidence of other viral infections (BK, JC), respectively, $20.8 \%$ vs $21 \%$ in HF and LF groups.

Moreover, we had tested correlation between other clinical features, RBC parameters, and presence of CMV reactivation signs. There were no significant connections found between donor RBC blood antigens, or donor/recipient $\mathrm{ABO}$ mismatch, and post-transplant infectious complications. Meanwhile, presence of A antigen (blood group II or IV) in the patients showed a highly significant correlation with CMV reactivation (CMV infection positive in 63\% (24/39) of $\mathrm{A}(+)$ patients versus $37 \%(14 / 51)$ in the group of $\mathrm{A}(-)$ patients $(\mathrm{r}=0.342 ; \mathrm{P}<0.01)$.

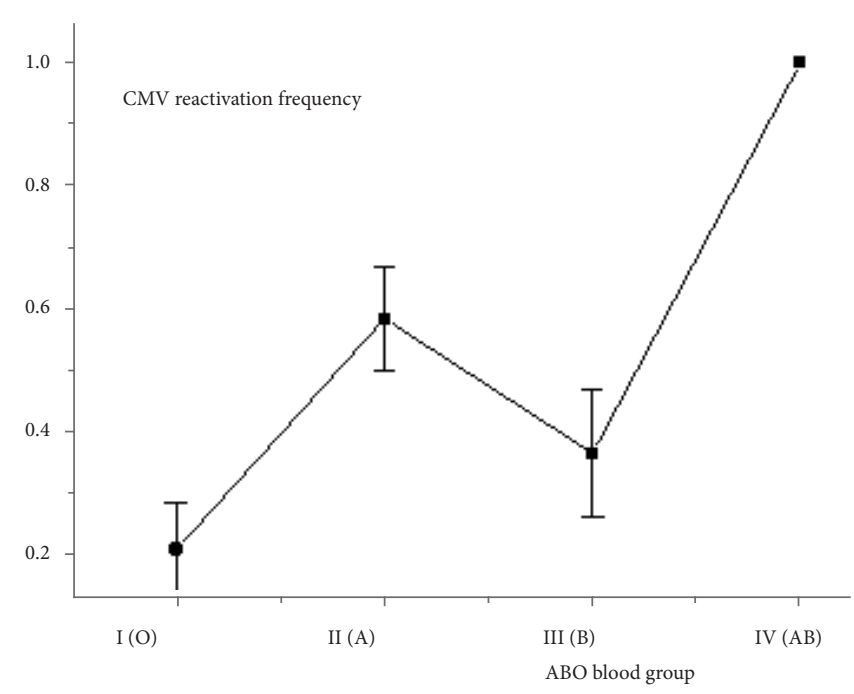

Fig. 2A. Dependence between RBC A antigen in recipients and CMV reactivation rates in the studied group $(n=91 ; p=0.003)$.

\section{Engraftment time}

The median time of neutrophil reconstitution $\left(\geq 500 \times 10^{9}\right)$ and platelet engraftment (Plt $\geq 20 \times 10^{9}$ ) were, respectively, 22 days (13-43) and 18 days (10-41) in HF group, versus 19.5 days (11-36) and 16.2 days (11-36) in LF group (Fig. 2). A significant HF/LF difference was noted for neutrophil recovery $(\mathrm{P}=0.047)$. Interestingly, that was independent of the stem cell dose infused: $5.2(1.3-14.1) \times 10^{6}$ versus $4.84(1.9-10.1) \times 10^{6}$ in HF and LF. Intensity of conditioning regimens did not also affect the engraftment rates in our cohort: MAC/RIC: 26.4/73.6\% and 29.5/71.5 \% in HF and LF groups, respectively.

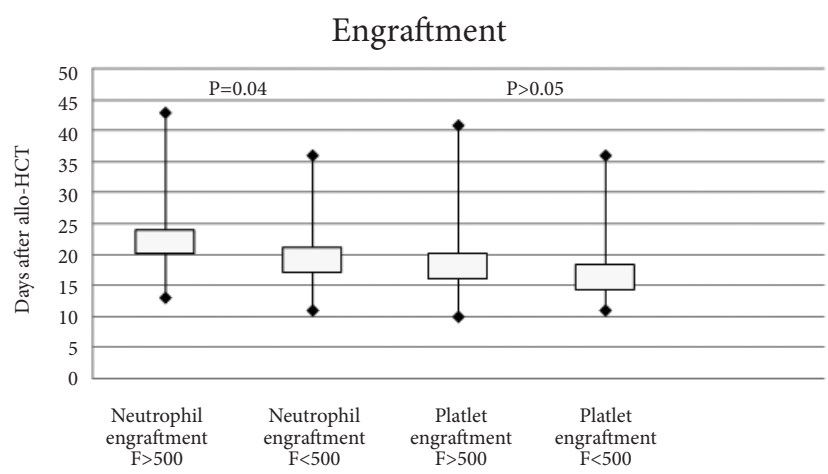

Fig. 2. Reconstitution of neutrophils and platelets in the initially low- and high-ferritin groups ( $F>$ or $<500 \mathrm{ng} /$ $\mathrm{mL}$ ). Abscisse: Designations for different sub-groups; ordinate: duration of the blood cell reconstitution, days.

\section{Hepatic veno-occlusive disease}

Only 4 cases were observed in total cohort: 3 , in HF and 1, in LF groups. The pre-HCT ferritin levels in these cases were as follows: $4247,1631,827.3,112 \mathrm{ng} / \mathrm{mL}$, and one case with primary myelofibrosis had severe VOD with multiorgan failure, and died on D7+ after transplantation. We did not find any significant statistical difference between the two groups $\mathrm{P}>0.05$, due to minimal statistics.

\section{Acute graft-versus-host disease}

Acute GvHD was diagnosed in 24 patients (45.28\%), and $18(47.36 \%)$ in HF and LF, respectively. This difference was not statistically significant $(\mathrm{P}>0.2)$. A tendency was noted towards higher occurence of severe aGvHD (Stage III-IV), including hepatic form in HF group (ferritin $\geq 500)(\mathrm{P}=0.07)$. That supports a theory that hepatic iron overload may imitate and worsen hepatic aGvHD.

\section{Pneumonia}

Increasing incidence of pneumonia was observed, regardless of its causes, in the first group (ferritin $\geq 500 \mathrm{ng} / \mathrm{mL}$ ) compared to the second group: 17 cases $(30.2 \%)$ vs 5 cases (13.15\%) in HF and LF, respectively $(\mathrm{P}=0.04$, [OR], 0.33 ; 95\%[CI], (0.11-0.99).

\section{Hemorrhagic cystitis}

Hemorrhagic cystitis was documented in 19 patients $(20 \%$ of total) with a median incidence on day 32 (range, 1-73). The median ferritin level was $716 \mathrm{ng} / \mathrm{ml}$ (12 to 1631), being similar in the HF and LF groups: 11 (20.75\%) vs 8 (21\%) in $\mathrm{HF}$ and LF groups, respectively $(\mathrm{P}>0.05)$.

\section{$\mathrm{RBC}$ transfusion requirements}

Number of RBC units transfused was counted for each patient within 100 days post-HCT, and a linear correlation was revealed between the increased pre -HCT ferritin and the number of $\mathrm{RBC}$ transfusions. Median number of RBC units/patient was 8.6 units ( 0 to 36 ) and 3.1 units ( 0 to 27 ) in HF and LF groups $\mathrm{P}=0.04$, [OR], 3.85 ; 95\%[CI], (0.9-15), as shown in Fig. 3(a).

In the same context, ferritin concentration was recorded only in 14 patients between days 70-100 post allo-HCT. Median 
ferritin level in this group was $2420 \mathrm{ng} / \mathrm{mL}$ (417 to 6362), at a mean number of 10.3 units per patient transfused in these cases ( 0 to 26). Meanwhile, the median initial ferritin level in this group was 943.4 (98 to 1850). Thus, we can conclude that

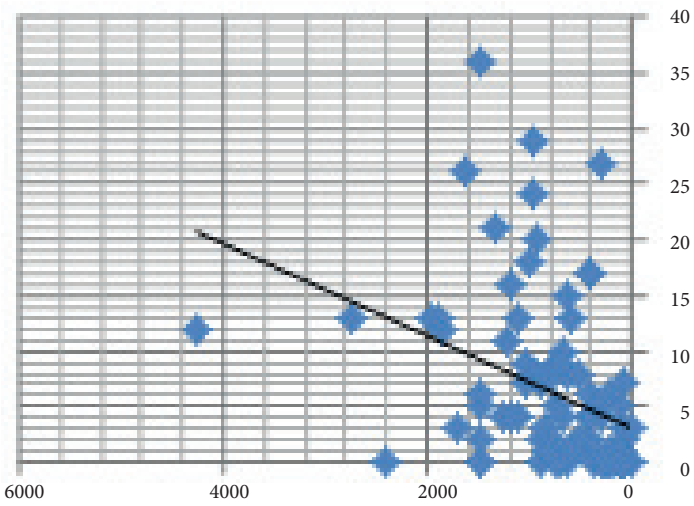

ferritin level pre allogeneic HSCT

a

$\mathrm{P}=0.04$ high ferritin levels at the 3rd month post-HCT in these cases may simply reflect an iron overload caused by multiple transfusions ( $1 \mathrm{RBC}$ unit contains 200 to $250 \mathrm{mg} \mathrm{Fe}$ ), as shown in the Fig. $3 a$ and $3 b$.

Fig. 3 (a). Linear correlation between the increased ferritin concentration pre-HCT and the number of RBC units transfused over 100 days post-HCT. (b) Steadily increased ferritin levels in group of patients $(n=14)$ in whom ferritin amounts were recorded in the third month after HCT, median number of RBC units transfused in these cases was 10.3 units /patient (range, 0-26).

\section{Early post-transplant mortality}

Fifteen patients died during 100 days: 12 (23\%) in HF, and $3(8 \%)$ in LF group, without any significant difference $(\mathrm{P}>0.05)$. Significant difference in the mortality which occurred in pre- and post-engraftment was observed: 5 fatal outcomes $(9.4 \%)$ were recorded only in HF group during the pre-engraftment period $(\mathrm{P}=0.003)$; resp., 8 cases $(15.1 \%)$ and one case $(2.6 \%)$ in HF and LF during 2 nd month of post-engraftment $(\mathrm{P}=0.02)$. Treatment-related mortality (TRM) was observed in 7 cases, five of them (9\%), in HF, and two (5\%), in LF group $(\mathrm{P}>0.05)$. Hence, we did not find any relationship between the ferritin concentrations (at the cutoff level of $500 \mathrm{ng} / \mathrm{mL}$ ), and mortality until the $\mathrm{D}+100$. However, on the basis of ROC analysis, we assumed the general median to be the cutoff value $(>773 \mathrm{ng} / \mathrm{mL}$ ) for ferritin, and revealed a statistical difference for the mortality by $\mathrm{D}+100$, i.e., 10 cases $(27.7 \%)$ in group with high ferritin $(\geq 773)$, and 5 lethal cases (9\%) in the low-ferritin group $(<773 \mathrm{ng} / \mathrm{mL}), \mathrm{P}=0.02$.

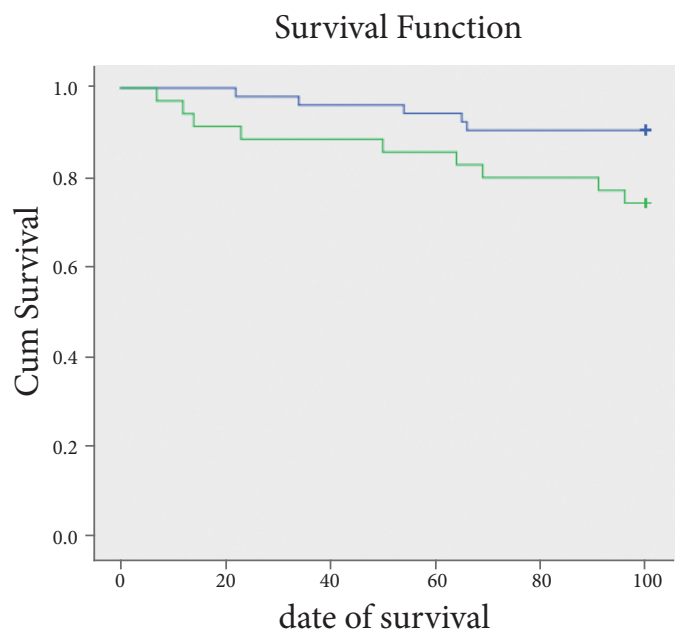

\section{Day 100 cumulative survival and disease-free survival}

With the cutoff ferritin concentration at $500 \mathrm{ng} / \mathrm{mL}$ (mean value of the sample), a significant statistical difference between two groups was not observed in the D100 cumulative survival and DFS: $77 \%$ and $62 \%$ in group 1 (ferritin $\geq 500$ ) vs $89 \%$ and $76 \%$ in group2 (ferritin $<500)$, respectively, $(\mathrm{P}>0.05)$.

However, when we considered serum ferritin cutoff value of $>773 \mathrm{ng} / \mathrm{mL}$ (the group median level), a significant statistical difference was observed. The D100 cumulative survival was $91 \%$ in group $(\mathrm{F}<773)$, vs $74 \%$ in HF group $(\mathrm{P}=0.04)$. D100 disease-free survival was $79 \%$ in group $(\mathrm{F}<773)$, versus $58 \%$ in group with high ferritin $(\mathrm{F} \geq 773), \mathrm{P}=0.019$. Hence, the preHSCT ferritin concentration at the over-median levels may be associated with lower OS and DFS, and could be considered as a risk factor (Fig. 4).

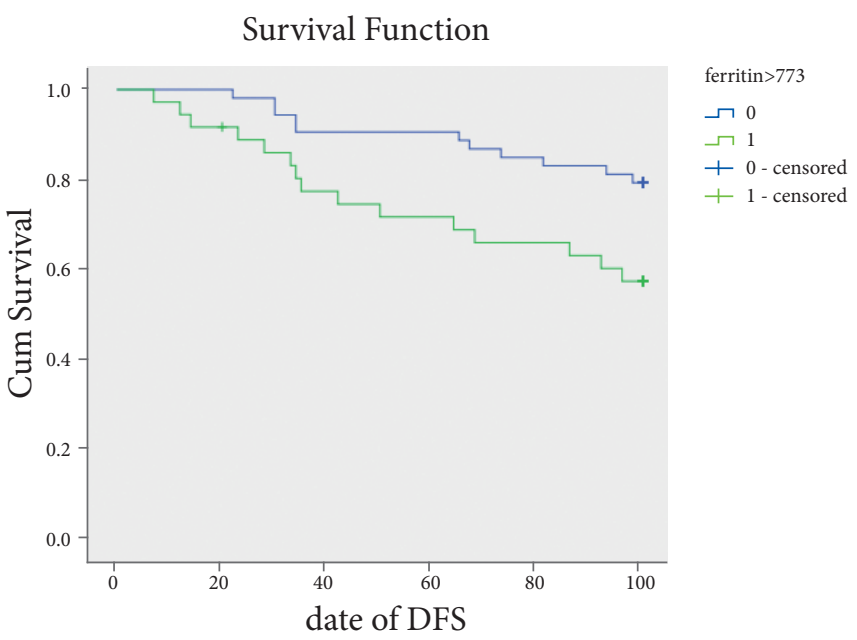

Fig. 4 Kaplan-Meier curves: D+100 cumulative survival and DFS in two groups at ferritin cutoff value of $\geq 773 \mathrm{ng} / \mathrm{mL}$. 


\section{Discussion}

The main objective of present study was to assess a predictive role of pre-allo-HCT ferritin concentrations, as a surrogate marker of iron overload in early transplant-related complications and outcome. The 500-ng/mL cutoff for serum ferritin concentration is less than in most previously reported series $[3,8]$. Our results suggest that a relatively mild iron overload in HCT recipients may also have toxic consequences. We did observe that high initial ferritin was significantly associated with increasing incidence of febrile neutropenia and bacterial infectious episodes, incidence of pneumonia and increased numbers of RBC units transfused post-HCT. Moreover, at an adjusted cutoff levels of ferritin ( $\geq 773 \mathrm{ng} / \mathrm{mL}$ ), we noted significant associations between the increased pre-HCT ferritin concentration and poor overall survival, disease-free survival and higher transplant-related mortality. An association between increased pre-HCT ferritin level and active infections, especially, pre-existing pulmonary aspergillosis, was statistically significant. Other common complications, including mucositis, acute GvHD and CMV infection, did not demonstrate significant associations with ferritin contents. Due to small number of VOD cases, we could not find significant relationship with increasing ferritin.

Iron overload is known to be associated with increased susceptibility to different infections. Iron deprivation was found to be the key factor in the antimicrobial host defense. E.g., Pullarkat et al. [22] showed in a group of 190 patients with hematological malignancies that developing severe infectious complications were significantly higher in the high-ferritin category $(\mathrm{OR}=1.99$, Wald test $\mathrm{P}=0.032)$. In contrast, $\mathrm{Su}$ cak et al. [24] showed no significant effect of pre-HCT iron status on bacteremia was observed $(\mathrm{P}>0.05)$. In our study, we have found that elevated pre transplant ferritin (>500 ng/ $\mathrm{mL}$ ) was associated with increasing number of febrile neutropenia episodes $(\mathrm{P}=0.005)$, bacterial infections $(\mathrm{P}=0.009)$. That may reflect a role of IO in severe immune defect and predisposition to recurrent bacterial infections. Therefore, high ferritin level, as a marker of general IO, seems to be a sufficient cofactor in severe transplant-associated infections.

Also, in accordance with recently published studies [26], we found a delayed engraftment and increased percentage of patients who required G-CSF stimulation in the HF group $(\mathrm{P}=0.005)$.

According to Sucak et al. [24] the pre-HSCT high ferritin concentration correlated with pneumonia in allogeneic HCT recipients, thus being consistent with our results, where increased ferritin level $(\geq 500)$ pre-HSCT proved to be associated with increasing pneumonia incidence $(\mathrm{P}=0.04)$. Interestingly, the cases of isolated bacterial pneumonia were also frequent in the group with high ferritin levels ( $\geq 500 \mathrm{ng} / \mathrm{mL}$ ) constituting $35.29 \%$ from causes of pneumonia in this group and this also confirms negative impact of iron overload in immunity, also as known bacteria need iron in their life cycle.

Some authors suggest a relationship between the pre-transplant ferritin levels and risk of invasive fungal infections (IFI) [2]. In contrast, other studies show that elevated serum ferri- tin $(\geq 1000 \mathrm{ng} / \mathrm{mL})$ was not a significant risk factor for IFI in a multivariate regression model after adjusting for aGvHD [7]. In our experience, there was a tendency for increased incidence of fungal infections among the patients with high ferritin concentration. However this group was too small for definite conclusions with no statistical significance $(\mathrm{P}>0.05)$.

There are conflicting results for relationship between acute GvHD and IO, while some studies suggest that the incidence of aGvHD was still associated with ferritin levels $\geq 1000 \mathrm{ng} /$ $\mathrm{mL}$ [22]. Another study has shown that ferritin levels over $1910 \mathrm{ng} / \mathrm{mL}$ correlate with a significantly lower incidence of acute GvHD, as well as limited and extensive chronic GvHD [18], thus supporting a hypothesis on suppressive effects of iron excess upon adaptive immune responses [6]. In our cohort, there was no correlation between a GvHD and elevated ferritin concentration pre-allo-HCT $(\mathrm{P}>0.05)$, but it was noted that there is a tendency for the occurrence of severe forms aGvHD III-IV, including the form of hepatic in the high-ferritin group, thus being in favor of a theory that hepatic iron overload may simulate or worsen hepatic aGvHD, since $90 \%$ of excessive iron is stored in the liver.

Several previous studies showed that elevated pre allo-HCT serum ferritin was an independent risk factor for SOS [20]. In our observation only $4(4.3 \%)$ cases of VOD were diagnosed, with initial median ferritin level of $1704.3 \mathrm{ng} / \mathrm{mL}$ (112-4247). Low number of the VOD cases may be due to use of RIC and non-MAC conditioning regimens, and the use of heparin prophylaxis, thus making it impossible to perform valid statistical evaluation. Because of the small VOD incidence no significant statistical difference between the two groups was observed $(\mathrm{P}>0.05)$.

We also observed that the patients with higher pre allo-HSCT ferritin levels required more blood transfusions than those in LF group. This may be attributed to presence of anti-RBC antibodies arising in heavily transfused patients [8] and to increasing incidence of febrile neutropenia and bacterial infections. Under the inflammatory conditions, hepcidin is secreted as a defensive mechanism, thus causing inhibition of iron release from its stores, thus preventing iron uptake for normal hematopoiesis and leading to slower recovery of erythroid lineage after HCT [2].

A number of previous studies, which used an indirect indicator of iron excess (serum ferritin) have found an association between the ferritin amounts and post-transplant survival using quite different threshold ferritin levels: $F \geq 3000$ [3]; $\mathrm{F} \geq 2515$ [4]; $\mathrm{F} \geq 1910$ [18]; $\mathrm{F} \geq 1000$ [16]; F $\geq 599$ [13] ; F $\geq 500$ [24]. Moreover, a negative impact of elevated ferritin proved to be associated with reduced overall and disease-free survival. However, when the pre-transplant IO was measured with MRI, such differences were not observed. E.g., Trottier et al. [27] did not find any association between pre-transplant iron excess defined by R2-MRI measured LIC and OS, NRM, relapse rate or GvHD. Similar results have been reported by Armand et al [4]. In our study, we observed significant correlation between pre allo-HCT ferritin $>773 \mathrm{ng} / \mathrm{mL}$ and increased mortality, reduced OS and DFS at the end of 100 days post HSCT. 
In conclusion, in accordance with previous findings, we observed increased incidence of infectious complications and adverse impact on engraftment rates. Serum ferritin may be considered the easiest way to estimate IO, being the most widely used method. Since serum ferritin is an acute phase reactant, its elevation may simply mirror inflammatory conditions, including an advanced disease phase that is shown to influence the outcomes in hematologic patients receiving allo-HSCT. The issue, whether high iron burden contributes directly to the poor outcome, or serum ferritin levels act as a surrogate marker for patient prognosis, requires further evaluation in prospective multicenter studies. Further studies using MRI assessment of tissue iron burden at various phases of HSCT, along with drawing appropriate correlations with clinical outcomes will be necessary in order to fully define the role of free iron in the patients undergoing HSCT.

\section{Conflict of interest}

None declared

\section{References}

1. Alessandrino EP, Della Porta MG, Bacigalupo A, Malcovati L, Angelucci E, Van Lint MT, Falda M, Onida F, Bernardi M, Guidi S, Lucarelli B, Rambaldi A, Cerretti R, Marenco P, Pioltelli P, Pascutto C, Oneto R, Pirolini L, Fanin R, Bosi A. Prognostic impact of pre-transplantation transfusion history and secondary iron overload in patients with myelodysplastic syndrome undergoing allogeneic stem cell transplantation: a GITMO study. Haematologica. 2010; 95: 476-484

2. Altes A, Remacha AF, Sarda P, Sancho FJ, Sureda A, Martino R, Briones J, Brunet S, Canals C, Sierra J. Frequent severe liver iron overload after stem cell transplantation and its possible association with invasive aspergillosis. Bone Marrow Transplant 2004; 34 (6):505-509.

3. Altes A, Remacha AF, Sarda P, Baiget M, Sureda A, Martino R, Briones J, Brunet S, Canals C, Sierra J. Early clinical impact of iron overload in stem cell transplantation. A prospective study. Ann Hematol. 2007; 86:443-447

4. Armand P, Sainvil MM, Kim HT, Rhodes J, Cutler C, Ho VT, Koreth J, Alyea EP, Neufeld EJ, Kwong RY, Soiffer RJ, Antin JH. Does iron overload really matter in stem cell transplantation? Am J Hematol. 2012; 87:569-572.

5. Ascioglu S, Rex JH, de Pauw B, Bennett JE, Bille J, Crokaert F, Denning DW, Donnelly JP, Edwards JE, Erjavec Z, Fiere D, Lortholary O, Maertens J, Meis JF, Patterson TF, Ritter J, Selleslag D, Shah PM, Stevens DA, Walsh TJ. Invasive Fungal Infections Cooperative Group of the European Organization for Research and Treatment of Cancer; Mycoses Study Group of the National Institute of Allergy and Infectious Diseases: Defining opportunistic invasive fungal infections in immunocompromised patients with cancer and hematopoietic stem cell transplants: an international consensus. Clin Infect Dis 2002; 34:7

6. Cunningham-Rundles S, Giardina PJ, Grady RW, Califano C, McKenzie P, De Sousa M. Effect of transfusional iron overload on immune response. J Infect Dis. 2000; 182 Suppl1: S115-121

7. Dadwal SS, Tegtmeier B, Liu X, Frankel P, Ito J, Forman SJ, Pullarkat V. Impact of pretransplant serum ferritin level on risk of invasive mold infection after allogeneic hemato-poietic stem cell transplantation Eur J Haematol. 2014 Aug 1. doi: 10.1111/ ejh. 12421.

8. Fluit CR, Kunst VA, Drenthe-Schonk AM. Incidence of red cell antibodies after multiple blood transfusion. Transfusion 1990; 30(6): 532-535.

9. Garcia-Vidal C, Upton A, Kirby KA, Marr KA. Epidemiology of invasive mold infections in allogeneic stem cell transplant recipients: biological risk factors for infection according to time after transplantation. Clin Infect Dis. 2008; 47:1041-1050

10. Giardini C, La Nasa G, Contu L, Galimberti M, Polchi P, Angelucci E, Baronciani D, Barbanti I, Muretto P, Lucarelli G. Desferrioxamine therapy induces clearance of iron deposits after bone marrow transplantation for thalassemia: case report. Bone Marrow Transplant. 1993;12 Suppl 1:108-110.

11. Gratwohl A, Hermans J, Apperley J, Arcese W, Bacigalupo A, Bandini G, di Bartolomeo P, Boogaerts M, Bosi A, Carreras E, et al. Acute graft-versus-host disease: grade and outcome in patients with chronic myelogenous leukemia. Working Party Chronic Leukemia of the European Group for Blood and Marrow Transplantation. Blood 1995, 86: 813-818.

12. Kanda J, Mizumoto C, Ichinohe T, Kawabata H, Saito T, Yamashita K, Kondo T, Takakura S, Ichiyama S, Uchiyama T, Ishikawa T. Pretransplant serum ferritin and C-reactive protein as predictive factors for early bacterial infection after allogeneic hematopoietic cell transplantation. Bone Marrow Transplant. 2011; 46:208-216.

13. Kataoka K, Nannya Y, Hangaishi A, Imai Y, Chiba S, Takahashi T, Kurokawa M. Influence of pretransplantation serum ferritin on nonrelapse mortality after myeloablative and nonmyeloablative allogeneic hematopoietic stem cell transplantation. Biol Blood Marrow Transplant 2009; 15(2): 195-204.

14. Knovich MA, Storey JA, Coffman LG, Torti SV, Torti FM. Ferritin for the clinician. Blood Rev 2009; 23 (3):95-104.

15. Kontoyiannis DP, Chamilos G, Lewis RE, Giralt S, Cortes J, Raad II, Manning JT, Han X. Increased bone marrow iron stores is an independent risk factor for invasive aspergillosis in patients with high-risk hematologic malignancies and recipients of allogeneic hematopoietic stem cell transplantation. Cancer. 2007; 110:1303-1306.

16. Lee JW, Kang HJ, Kim EK, Kim H, Shin HY, Ahn HS. Effect of iron overload and iron-chelating therapy on allogeneic hematopoietic SCT in children. Bone Marrow Transplant. 2009; 44 (12):793-797.

17. McDonald GB, Hinds MS, Fisher LD, Schoch HG, Wolford JL, Banaji M, Hardin BJ, Shulman HM, Clift RA. Veno-occlusive disease of the liver and multiorgan failure after bone marrow transplantation: a cohort study of 355 patients. Ann Int Med 1993; 118 (4):255-257. 
18. Mahindra A, Sobecks R, Rybicki L, Pohlman B, Dean R, Andresen S, Kalaycio M, Sweetenham J, Bolwell B, Copelan E. et al. Elevated pretransplant serum ferritin is associated with inferior survival following nonmyeloablative allogeneic transplantation. Bone Marrow Transplant 2009; 44: 767-768.

19. Majhail NS, DeFor T, Lazarus HM, Burns LJ. High prevalence of iron overload in adult allogeneic hematopoietic cell transplant survivors. Biol Blood Marrow Transplant. 2008; 14(7): 790-794.

20. Maradei SC, Maiolino A, de Azevedo AM, Colares M, Bouzas LF, Nucci M. Serum ferritin as risk factor for sinusoidal obstruction syndrome of the liver in patients undergoing hematopoietic stem cell transplantation. Blood 2009; 114 (6):1270-1275.

21. Piperno A. Classification and diagnosis of iron overload. Haematologica 1998; 83: 447-455

22. Pullarkat V, Blanchard S, Tegtmeier B, Dagis A, Patane K, Ito J, Forman SJ. Iron overload adversely affects outcome of allogeneic hematopoietic cell transplantation. Bone Marrow Transplant. 2008; 42:799-805

23. Siah CW, Ombiga J, Adams LA, Trinder D, Olynyk JK. Normal iron metabolism and the pathophysiology of iron overload disorders. Clin Biochem Rev 2006; 27: 5-16
24. Sucak GT, Yegin ZA, Ozkurt ZN, Aki SZ, Yağci M. Iron overload: predictor of adverse outcome in hematopoietic stem cell transplantation. Transplant Proc 2010; 42 (5):1841-1848.

25. Tachibana T, Tanaka M, Takasaki H, Numata A, Ito S, Watanabe R, Hyo R, Ohshima R, Hagihara M, Sakai R, Fujisawa S, Tomita N, Fujita H, Maruta A, Ishigatsubo Y, Kanamori $H$. Pretransplant serum ferritin is associated with bloodstream infections within 100 days of allogeneic stem cell transplantation for myeloid malignancies. Int J Hematol 2011; 93:368-374.

26. Tanaka M, Kanamori H, Matsumoto K, Tachibana T, Numata A, Ohashi K, Kobayashi T, Nakaseko C, Kanda Y, Yamazaki E, Fujisawa S, Ooi J, Sakura T, Aotsuka N, Onoda M, Machida S, Kato J, Usuki K et al., Clinical significance of pretransplant serum ferritin on the outcome of allogeneic hematopoietic SCT: a prospective cohort study by the Kanto Study Group for Cell Therapy. Bone Marrow Transplantation 2015, 50 (5):727-733

27. Trottier BJ, Burns LJ, DeFor TE, Cooley S, Majhail NS. Association of iron overload with survival and complications in allogeneic hematopoietic cell transplant recipients: prospective cohort study using R2-MRI measured liver iron content. Blood 2013; 122:1678-1684. 